\title{
Shoreline Changes due to Abrasion in Pekalongan Utara Sub District Year 2003- 2018
}

\author{
Ndaru Diatama, Chatarina Muryani, Rahning Utomowati \\ Universitas Sebelas Maret \\ ndarudiatama@student.uns.ac.id
}

\section{Article History}

accepted 31/08/2020

approved 22/09/2020

published 28/10/2020

\begin{abstract}
The purpose of this research are: 1) analyze the shoreline change in the coastal areas of North Pekalongan Sub-district from 2003 to 2018; 2) Analyze the land use change in the coastal areas of North Pekalongan from 2003 to 2018; This type of research is a qualitative descriptive with a spatial approach. Data obtained from interpretation of IKONOS image from Google Earth in 2003, year 2013, and year 2018. The research steps were: (1) interpretation of Google Earth IKONOS image year 2003-2018, (2) Overlay of shoreline map of year 2003 and year 2018, (3) overlay of land use maps of year 2003- year 2018. The results of the study were: (1) The shoreline of North Pekalongan Sub-district was retreat 7.261 meters up to 94.383 meters. (2) The largest land use changes in North Pekalongan sub district was the change of land to a flooded land of 624.379 ha or $52.556 \%$ of land in the area.
\end{abstract}

Keywords: shoreline change, land use change, image, GIS

\section{Abstrak}

Tujuan dari penelitian ini adalah: 1) menganalisis perubahan garis pantai di wilayah pesisir Kecamatan Pekalongan Utara dari tahun 2003 hingga 2018; 2) Menganalisis perubahan penggunaan lahan di wilayah pesisir Pekalongan Utara dari tahun 2003 hingga 2018; Jenis penelitian yang digunakan adalah deskriptif kualitatif dengan pendekatan spasial. Data diperoleh dari interpretasi citra IKONOS dari Google Earth tahun 2003, tahun 2013, dan tahun 2018. Langkah-langkah penelitian yang dilakukan adalah: (1) interpretasi citra IKONOS Google Earth tahun 2003-2018, (2) Overlay peta garis pantai tahun 2003 dan tahun 2018, (3) overlay peta tata guna lahan tahun 2003 - tahun 2018. Hasil penelitian adalah: (1) Garis pantai Kecamatan Pekalongan Utara mengalami kemunduran 7.261 meter sampai dengan 94.383 meter. (2) Perubahan penggunaan lahan terbesar di Kecamatan Pekalongan Utara adalah perubahan lahan menjadi lahan tergenang seluas 624.379 ha atau $52.556 \%$ dari luas lahan di wilayah tersebut.

Kata kunci: perubahan garis pantai, perubahan penggunaan lahan, citra, SIG

Social, Humanities, and Education Studies (SHEs): Conference Series https://jurnal.uns.ac.id/shes 


\section{PENDAHULUAN}

Wilayah pesisir menghadapi berbagai tekanan, perkembangan, dan perubahan. Fenomena tersebut mendorong semua pihak untuk melaksanakan perencanaan dan pengelolaan pesisir sesuai kondisi alamiahnya yang harus berorientasi pada penyelamatan lingkungan ekosistemnya. Wilayah pesisir semakin menghadapi tekanan tinggi dari aktivitas alami seperti angin dan gelombang yang berdampak pada dinamika bentang lahan. Selain itu, wilayah pesisir juga menerima berbagai dampak yang disebabkan oleh aktivitas manusia, sebagai contohnya beban bangunan serta ekstraksi air tanah besar besaran yang menyebabkan penurunan permukaan tanah/ land subsidence.

Perubahan garis pantai secara umum berlangsung dengan lambat, namun jika didukung oleh faktor-faktor (alami maupun tidak alami) penyebab terjadinya perubahan garis pantai maka memungkinkan perubahan tersebut terjadi sangat cepat. Ongkosongo (2006 : 59) mengemukakan bahwa sekitar $70 \%$ pantai terutama berpasir di dunia mengalami erosi pantai dan penyebab utama adalah aneka ragam pengaruh manusia secara langsung maupun tak langsung yang menyebabkan berkurangnya jumlah ketersedian cadangan sedimen yang ada di pantai dibandingkan dengan sedimen keluar dari pantai akibat pengaruh alam.

Perubahan garis pantai yang terjadi di kawasan pantai berupa pengikisan badan pantai (abrasi) dan penambahan badan pantai (sedimentasi atau akresi). Proses-proses tersebut terjadi sebagai akibat dari pergerakan sedimen, arus, dan gelombang yang berinteraksi dengan kawasan pantai secara langsung.

Perubahan garis pantai mempengaruhi dinamika penggunaan lahan di Kecamatan Pekalongan Utara. Garis pantai mundur mengakibatkan lahan terdesak, akhirnya lahan akan rusak bahkan hilang. Begitu pula pantai yang maju dapat menghasilkan lahan baru yang dapat dimanfaatkan oleh masyarakat.

Berdasarkan data statistik penggunaan lahan yang berubah signifikan adalah sawah. Di Kota Pekalongan luas lahan sawah setiap tahunnya selalu berkurang. Pada tahun 2016 hingga 2017, luas tanah sawah mengalami pengurangan drastis sebesar 104 ha. Lahan budidaya tambak juga menjadi tidak produktif akibat tingginya genangan dari kenaikan muka air laut yang terjadi. Kemudian secara keseluruhan untuk perubahan penggunaan lahan yang telah terjadi di Kota Pekalongan dalam periode waktu tahun 2003 sampai tahun 2018 sudah banyak mengalami perubahan pemanfaatan dikarenakan salah satu faktornya adalah perubahan garis pantai. Kondisi tersebut tentunya akan mengakibatkan terbentuknya pola penyebaran penggunaan lahan yang tidak optimal.

Berdasarkan data statistik penggunaan lahan yang berubah signifikan adalah sawah. Di Kota Pekalongan luas lahan sawah setiap tahunnya selalu berkurang. Pada tahun 2016 hingga 2017, luas tanah sawah mengalami pengurangan drastis sebesar 104 ha. Lahan budidaya tambak juga menjadi tidak produktif akibat tingginya genangan dari kenaikan muka air laut yang terjadi. Kemudian secara keseluruhan untuk perubahan penggunaan lahan yang telah terjadi di Kota Pekalongan dalam periode waktu tahun 2003 sampai tahun 2018 sudah banyak mengalami perubahan pemanfaatan dikarenakan salah satu faktornya adalah perubahan garis pantai. Kondisi tersebut tentunya akan mengakibatkan terbentuknya pola penyebaran penggunaan lahan yang tidak optimal.

Perubahan penggunaan lahan akibat bergesernya garis pantai juga akan mempengaruhi kondisi sosial ekonomi masyarakat. Sosial ekonomi yang berubah antara lain adalah perubahan pendapatan karena adanya kerugian dari masyarakat yang mata pencahariannya sebagai petani tambak dan petani sawah. Hal tersebut dikarenakan adanya banjir rob di lokasi penelitian sehingga petani sawah dan petani tambak pun kehilangan sumber penghasilannya. Hal tersebut tentu akan merugikan petani, bahkan petani sawah yang kehilangan lahan pertanian akan mencari mata 
pencaharian lainnya sehingga akan merubah kondisi sosial ekonomi penduduk yang terdampak oleh perubahan garis pantai. Menurut data statistik total tenaga kerja menurut lapangan usaha utama di Kota Pekalongan pada tahun 2014 menuju ke tahun 2015 terjadi penurunan tenaga kerja petani dari 4,65\% turun menjadi 2,91\%. Akan tetapi ada beberapa peningkatan pada beberapa sektor usaha seperti sektor industri dan perdagangan. Data ini memunculkan pendapat bahwa telah terjadi perubahan kondisi sosial ekonomi masyarakat Kota Pekalongan

\section{METODE}

Lokasi penelitian adalah pesisir Kecamatan Pekalongan Utara meliputi Kelurahan Bandengan, Kandangpanjang, Panjang Wetan, Krapyak Lor, dan Degayu..

Data sekunder yang digunakan dalam penelitian ini adalah data garis pantai dan penggunaan lahan yang diperoleh melalui interpretasi citra IKONOS Google Earth tahun 2003, tahun 2013, dan tahun 2018. Data primer adalah data wawancara dengan penduduk yang terdampak. Tahapan penelitian meliputi: (1) interpretasi citra IKONOS Google Earth tahun 2003-2018, (2) Overlay peta garis pantai tahun 2003-2018, (3) Menganalisis perubahan garis pantai tahun 2003-2018.

Sedangkan perubahan penggunaan lahan tahapannya hampir sama dengan penghitungan garis pantai, tetapi ditambah dengan kunci interpretasi citra

Bagian ini disajikan jika artikel merupakan hasil penelitian (hasil kajian tidak perlu menyajikan bagian ini). Bagian ini disajikan maksimal 200 kata. Bagian ini dipaparkan pendekatan dan/atau metode penelitian, data dan sumber data, teknik dan alat pengumpulan data, serta teknik analisi data yang digunakan.

\section{HASIL DAN PEMBAHASAN}

Garis pantai pada 6 kelurahan di Kecamatan Pekalongan Utara mengalami dinamika yang berbeda. Perubahan garis pantai akan berakibat pada perubahan penggunaan lahan. Data perubahan garis pantai dan penggunaan lahan masingmasing kelurahan adalah sebagai berikut

1) Kelurahan Krapyak

Perubahan garis pantai di Kelurahan Krapyak periode tahun 2003 sampai 2018 disajikan dalam tabel 1 berikut:

Tabel 1 Perubahan garis pantai Kelurahan Krapyak periode tahun 2003 sampai 2018

\begin{tabular}{ccc}
\hline Titik & $\begin{array}{c}\text { Perubahan garis } \\
\text { pantai }(\mathrm{m})\end{array}$ & Keterangan \\
\hline $\mathrm{Q}$ & $-23,386$ & Mundur \\
$\mathrm{R}$ & 63,205 & Maju \\
$\mathrm{S}$ & 102,052 & Maju \\
\hline
\end{tabular}

Sumber : Pengolahan Citra IKONOS Google Earth tahun 2013 dan 2018

Dari data di atas diketahui bahwa garis pantai maju terjauh adalah 102,052 meter di titik S, sedangkan garis pantai mundur adalah sebesar 23,386 meter di titik $Q$.

Hasil analisis perubahan penggunaan lahan Kelurahan Krapyak periode tahun 2003 dan tahun 2018 adalah sebagai berikut:

Tabel 2 Perubahan penggunaan lahan Kelurahan Krapyak tahun 2003- 2018

\begin{tabular}{clc}
\hline No & Perubahan Lahan & Luas lahan (ha) \\
\hline 1 & Permukiman - & 0,531 \\
& Lahan Tergenang & \\
2 & Sawah - Lahan & 26,582
\end{tabular}




\begin{tabular}{llc} 
& Tergenang & \\
3 & Sawah - & 11,262 \\
& Permukiman \\
4 & $\begin{array}{l}\text { Tambak - Lahan } \\
\text { Tergenang }\end{array}$ \\
5 & $\begin{array}{l}\text { Tambak - } \\
\text { Permukiman }\end{array}$ & 157,514 \\
6 & Tambak - Sawah \\
7 & $\begin{array}{l}\text { Tetap/ Tidak ada } \\
\text { perubahan } \\
\text { penggunaan lahan }\end{array}$ & 0,653 \\
& \multicolumn{2}{c}{ Jumlah Sumber : Hasil overlay interpretasi Citra IKONOS }
\end{tabular}

Berdasar tabel 2 terlihat bahwa perubahan penggunaan lahan yang paling luas adalah perubahan lahan tambak menjadi lahan tergenang yaitu seluas 157,514 ha. Untuk lahan yang tidak berubah seluas 127,785 ha.

2) Kelurahan Panjangbaru

Perubahan garis pantai di Kelurahan Panjangbaru periode tahun 2003 sampai 2018 adalah sebagai berikut:

Tabel 3 Perubahan garis pantai Kelurahan Panjangbaru periode tahun 2003 sampai 2018

\begin{tabular}{ccc}
\hline Titik & $\begin{array}{c}\text { Perubahan garis } \\
\text { pantai }(\mathrm{m})\end{array}$ & Keterangan \\
\hline $\mathrm{I}$ & $-15,428$ & Mundur \\
$\mathrm{J}$ & $-7,261$ & Mundur \\
$\mathrm{K}$ & $-14,129$ & Mundur \\
$\mathrm{L}$ & $-19,285$ & Mundur \\
$\mathrm{M}$ & $-25,242$ & Mundur \\
\hline
\end{tabular}

Sumber : Pengolahan Citra IKONOS Google Earth tahun 2013 dan 2018

Berdasarkan tabel 3 dapat diketahui garis pantai di Kelurahan Panjangbaru Sebagian besar pmundur, dan terbesar mundur 25,242 meter di titik M.

Hasil analisis perubahan penggunaan lahan Kelurahan Panjangbaru periode tahun 2003-2018 adalah berikut:

Tabel 4 Perubahan penggunaan lahan Kelurahan Panjangbaru periode tahun 2003 - 2018

\begin{tabular}{llc}
\hline No & Perubahan Lahan & Luas lahan (ha) \\
\hline 1 & Permukiman - & 28,919 \\
2 & $\begin{array}{l}\text { Lahan Tergenang } \\
\text { Tambak - Lahan }\end{array}$ & 26,977 \\
3 & $\begin{array}{l}\text { Tergenang } \\
\text { Tambak - }\end{array}$ & 5,066 \\
4 & $\begin{array}{l}\text { Permukiman } \\
\text { Tetap/ Tidak ada } \\
\text { perubahan } \\
\text { penggunaan lahan }\end{array}$ & 51,510 \\
\hline & $\quad$ Jumlah & 112,472 \\
\hline
\end{tabular}


Sumber : Hasil overlay interpretasi Citra IKONOS Google Earth tahun 2003 dan tahun 2018 Kelurahan Panjangbaru Kecamatan Pekalongan Utara

Berdasar tabel di atas terlihat bahwa perubahan penggunaan lahan yang paling luas adalah perubahan lahan permukiman menjadi lahan tergenang seluas 28,919 ha. Untuk lahan yang tidak berubah seluas 51,510 ha.

3) Kelurahan Degayu

Perubahan garis pantai di Kelurahan Degayu periode tahun 2003 -2018 adalah sebagai berikut:

Tabel 5 Perubahan garis pantai Kelurahan Degayu periode tahun 2003 -2018

\begin{tabular}{ccc}
\hline Titik & $\begin{array}{c}\text { Perubahan garis } \\
\text { pantai }(\mathrm{m})\end{array}$ & Keterangan \\
\hline $\mathrm{T}$ & 110,952 & Maju \\
$\mathrm{U}$ & $-30,770$ & Mundur \\
$\mathrm{V}$ & $-77,964$ & Mundur \\
$\mathrm{W}$ & $-67,865$ & Mundur \\
$\mathrm{X}$ & $-83,461$ & Mundur \\
\hline
\end{tabular}

Sumber : Pengolahan Citra IKONOS Google Earth tahun 2013 dan 2018

Berdasarkan tabel di atas terlihat bahwa garis pantai maju sebesar 110,952 meter yaitu dititik T dan pantai yang mundur terbesar 83,461 meter di titik X.

Hasil analisis perubahan penggunaan lahan Kelurahan Degayu tahun 20032018 adalah sebagai berikut:

Tabel 6 Perubahan penggunaan lahan Kelurahan Degayu tahun 2003-2018

\begin{tabular}{llc}
\hline No & Perubahan Lahan & Luas lahan (ha) \\
\hline 1 & Permukiman - Sawah & 0,018 \\
2 & Sawah - Lahan & 13,38 \\
& Tergenang & 2,57 \\
3 & Sawah - Permukiman & 153,146 \\
4 & Tambak - Lahan & 0,212 \\
& Tergenang & 72,265 \\
5 & Tambak - & \\
& Permukiman & \\
& Tetap/ Tidak ada & perubahan \\
& penggunaan lahan & 241,591
\end{tabular}

Sumber : Hasil overlay interpretasi Citra IKONOS

Berdasar tabel di atas terlihat bahwa perubahan penggunaan lahan terluas adalah lahan tambak menjadi lahan tergenang seluas 153,146 ha. Untuk lahan yang tidak berubah seluas 72,265 ha.

4) Kelurahan Kandang Panjang

Perubahan garis pantai di Kelurahan Kandang Panjang tahun 2003-2018 adalah sebagai berikut:

Tabel 7 Perubahan garis pantai Kelurahan Kandang Panjang tahun 2003- 2018 


\begin{tabular}{ccc}
\hline Titik & $\begin{array}{c}\text { Perubahan garis } \\
\text { pantai }(\mathrm{m})\end{array}$ & Keterangan \\
\hline $\mathrm{F}$ & $-61,998$ & Mundur \\
$\mathrm{G}$ & $-26,261$ & Mundur \\
$\mathrm{H}$ & $-46,172$ & Mundur \\
\hline
\end{tabular}

Sumber : Pengolahan Citra IKONOS Google Earth

Berdasarkan tabel di atas dapat diketahui bahwa garis pantai mundur terbanyak adalah 61,998 meter di titik F.

Perubahan penggunaan lahan Kelurahan Kandang Panjang periode tahun 2003-2018 adalah sebagai berikut:

Tabel 8 Perubahan penggunaan lahan Kelurahan Kandang Panjang tahun 2003-2018

\begin{tabular}{llc}
\hline No & Perubahan Lahan & Luas lahan (ha) \\
\hline 1 & Permukiman - Lahan & 0,513 \\
& Tergenang & 95,389 \\
2 & $\begin{array}{l}\text { Tambak - Lahan } \\
\text { Tergenang }\end{array}$ & 5,394 \\
& $\begin{array}{l}\text { Tambak - } \\
\text { Permukiman }\end{array}$ & 54,392 \\
& $\begin{array}{l}\text { Tetap/ Tidak ada } \\
\text { perubahan } \\
\text { penggunaan lahan }\end{array}$ & \\
\hline & $\quad$ Jumlah & 155,688 \\
\hline
\end{tabular}

Sumber : Hasil overlay interpretasi Citra IKONOS Google Earth

Berdasar tabel di atas terlihat perubahan penggunaan lahan yang paling luas adalah permukiman menjadi lahan tergenang seluas 95,389 ha. Untuk lahan yang tidak berubah seluas 54,392 ha.

5) Kelurahan Panjang Wetan

Perubahan garis pantai di Kelurahan Panjang Wetan periode tahun 2003-2018 adalah sebagai berikut:

Tabel 9 Perubahan garis pantai Kelurahan Panjang Wetan periode tahun 2003-2018

\begin{tabular}{ccc}
\hline Titik & $\begin{array}{c}\text { Perubahan garis } \\
\text { pantai }(\mathrm{m})\end{array}$ & Keterangan \\
\hline $\mathrm{N}$ & $-14,225$ & Mundur \\
$\mathrm{O}$ & $-18,944$ & Mundur \\
$\mathrm{P}$ & $-40,296$ & Mundur \\
\hline
\end{tabular}

Sumber : Pengolahan Citra IKONOS Google Earth tahun 2013 dan 2018

Berdasarkan tabel di atas dapat diketahui bahwa pada garis pantai yang mundur paling banyak sebesar 40,296 meter di titik P. Sedangkan mundur yang paling sedikit adalah sebesar 14,225 meter di titik N.

Hasil analisis perubahan penggunaan lahan Kelurahan Panjang Wetan periode tahun 2003-2018 adalah sebagai berikut:

Tabel 10 Perubahan penggunaan lahan Kelurahan Panjang Wetan periode tahun 2003-2018 


\begin{tabular}{llc}
\hline 1 & Permukiman - & 10,849 \\
& $\begin{array}{l}\text { Lahan Tergenang } \\
\text { Tambak - }\end{array}$ & 0,01 \\
3 & $\begin{array}{l}\text { Permukiman } \\
\text { Tetap/ Tidak ada } \\
\text { perubahan } \\
\text { penggunaan lahan }\end{array}$ & 104,668 \\
\hline & Jumlah & 115,527 \\
\hline
\end{tabular}

Sumber : Hasil overlay interpretasi Citra IKONOS Google Earth

Berdasar tabel di atas terlihat bahwa terdapat 2 perubahan penggunaan lahan di Kelurahan Panjang Wetan. Yaitu perubahan lahan permukiman menjadi lahan tergenang yaitu seluas 10,849 ha. Dan perubahan penggunaan lahan tambak menjadi lahan permukiman yaitu seluas 0,01 ha. Untuk lahan yang tidak berubah seluas 104,668 ha.

6) Kelurahan Bandengan

Perubahan garis pantai di Kelurahan Bandengan periode tahun 2003-2018 adalah sebagai berikut:

Tabel 11 Perubahan garis pantai Kelurahan Bandengan periode tahun 2003- 2018

\begin{tabular}{ccc}
\hline Titik & $\begin{array}{c}\text { Perubahan garis } \\
\text { pantai }(\mathrm{m})\end{array}$ & Keterangan \\
\hline A & $-58,448$ & Mundur \\
B & $-40,842$ & Mundur \\
C & $-56,096$ & Mundur \\
D & $-46,000$ & Mundur \\
E & $-94,383$ & Mundur \\
\hline
\end{tabular}

Sumber : Pengolahan Citra IKONOS Google Earth tahun 2013 dan 2018

Berdasarkan tabel di atas dapat diketahui di kelurahan Bandengan periode tahun 2003-2018 seluruhnya mengalami mundur garis pantai. Garis pantai yang mundur paling banyak sebesar 94,383 meter di titik E

Hasil analisis perubahan penggunaan lahan Kelurahan Bandengan periode tahun 2003-2018 adalah sebagai berikut:

Tabel 12 Perubahan penggunaan lahan Kelurahan Bandengan tahun 2003-2018

\begin{tabular}{llc}
\hline No & Perubahan Lahan & Luas lahan (ha) \\
\hline 1 & Permukiman - & 3,648 \\
& $\begin{array}{l}\text { Lahan Tergenang } \\
2\end{array}$ & $\begin{array}{l}\text { Tambak - Lahan } \\
\text { Tergenang }\end{array}$ \\
3 & $\begin{array}{l}\text { Tambak - } \\
\text { Permukiman }\end{array}$ & 0,136 \\
4 & $\begin{array}{l}\text { Tetap/ Tidak ada } \\
\text { perubahan } \\
\text { penggunaan lahan }\end{array}$ & 15,993 \\
\hline & Jumlah & 210,998 \\
\hline
\end{tabular}

Sumber : Hasil overlay interpretasi Citra IKONOS Google Earth 
Perubahan penggunaan lahan yang paling luas adalah perubahan lahan permukiman menjadi lahan tergenang yaitu seluas 191,221 ha. Untuk lahan yang tidak berubah seluas 15,993 ha.

7) Perubahan penggunaan lahan di Kawasan Pesisir Kecamatan Pekalongan Utara dari tahun 2003 sampai dengan 2018

Perubahan penggunaan lahan Kecamatan Pekalongan Utara tahun 2003 -2018 adalah sebagai berikut:

Tabel 13 Perubahan penggunaan lahan Kecamatan Pekalongan Utara periode tahun 2003 dan tahun 2018

\begin{tabular}{|c|c|c|}
\hline No & Perubahan Lahan & Luas lahan (ha) \\
\hline 1 & $\begin{array}{l}\text { Permukiman - Lahan } \\
\text { Tergenang }\end{array}$ & 44,461 \\
\hline 2 & Permukiman - Sawah & 0,018 \\
\hline 3 & $\begin{array}{l}\text { Sawah - Lahan } \\
\text { Tergenang }\end{array}$ & 39,962 \\
\hline 4 & Sawah - Permukiman & 13,832 \\
\hline 5 & $\begin{array}{l}\text { Tambak - Lahan } \\
\text { Tergenang }\end{array}$ & 624,379 \\
\hline 6 & $\begin{array}{l}\text { Tambak - } \\
\text { Permukiman }\end{array}$ & 38,471 \\
\hline $\begin{array}{l}7 \\
8\end{array}$ & $\begin{array}{l}\text { Tambak - Sawah } \\
\text { Tetap/ Tidak ada } \\
\text { perubahan } \\
\text { penggunaan lahan }\end{array}$ & $\begin{array}{c}0,296 \\
426,613\end{array}$ \\
\hline & Jumlah & 1188,031 \\
\hline
\end{tabular}

Sumber : Hasil overlay interpretasi Citra IKONOS Google Earth

Dari tabel $d$ atas secara keseluruhan, 6 kelurahan di Kecamatan Pekalongan Utara pada periode tahun 2003 dan 2018 terjadi 7 jenis perubahan lahan. Perubahan lahan yang paling besar adalah perubahan lahan dari lahan tambak menjadi lahan tergenang yaitu sebesar 624,379 ha. Untuk lahan yang tidak berubah atau yang tetap yaitu sebesar 426,613 ha. Peta perubahan penggunaan lahan di Kecamatan Pekalongan Utara tahun 2003-2018 sebagai berikut:

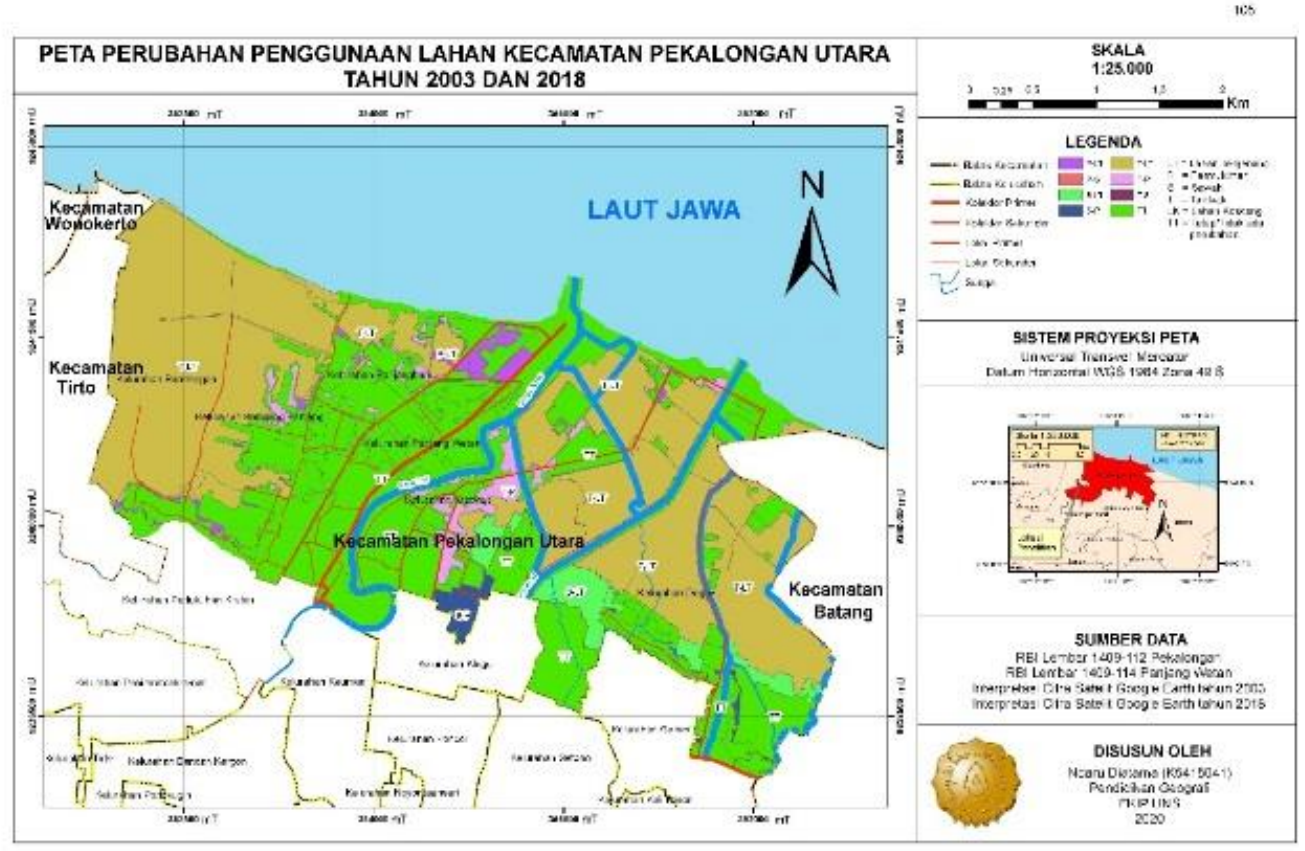


Gambar 1. Peta Perubahan Penggunaan Lahan Kecamatan Pekalongan Utara Tahun 2003 dan 2018

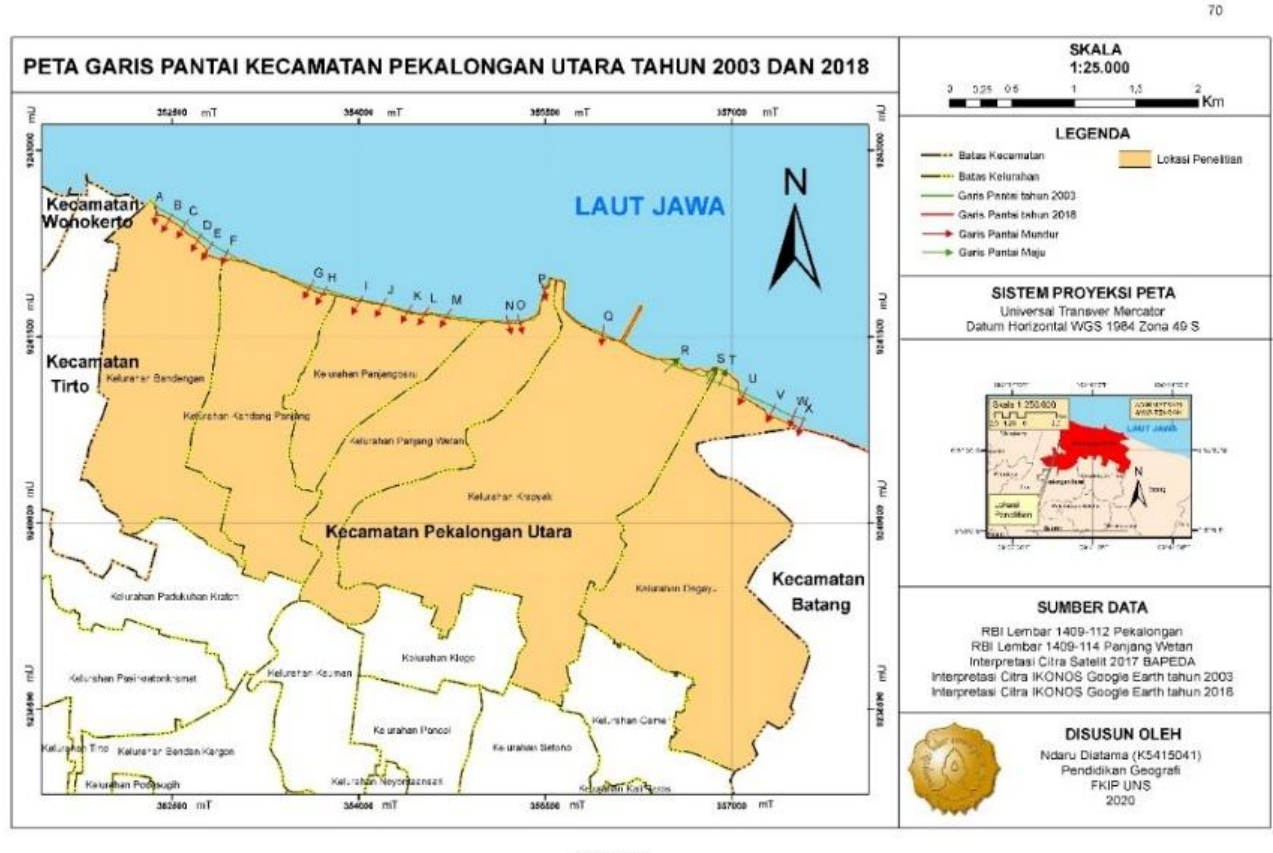

Gambar 2. Peta Garis Pantai Kecamatan Pekalongan Utara Tahun 2003 dan 2018

\section{SIMPULAN}

1. Perubahan garis pantai di Kecamatan Pekalongan Utara periode 2003-2018 adalah sebagai berikut :

a. Daerah di Kecamatan Pekalongan Utara mengalami mundur garis pantai sebesar 7,261 meter sampai dengan 94,383 meter

b. Daerah di Kecamatan Pekalongan Utara ada yang mengalami maju garis pantai sebesar 63,205 meter sampai dengan 110,952 meter

c. Kelurahan yang mengalami maju garis pantai terbesar di Kelurahan Degayu. sepanjang 110,952 meter.

2. Perubahan penggunaan lahan terbesar di Kecamatan Pekalongan Utara tahun 2003-2018 adalah lahan tambak menjadi lahan tergenang yaitu sebesar 624,379 ha atau sebesar 52,556\% lahan di Kecamatan Pekalongan Utara

\section{DAFTAR PUSTAKA}

Anderson, James. 2001. A Land Use And Land Cover Classification System For Use With Remote Sensing Data. Washington : United States Goverment Printing Office

Arief et al. 2017. Kajian Perubahan Garis Pantai Menggunakan Data Satelit Landsat Di Kabupaten Kendal. Peneliti Pusat Pemanfaatan Penginderaan Jauh. Jurnal. LAPAN

Arsyad, Sintalana. 1989. Konservasi Tanah dan Air. Bandung: Institut Pertanian Bogor Assyakur, dkk. 2010. Studi Perubahan Penggunaan Lahan di DAS Badung. Bali: Pusat Penelitian Lingkungan Hidup Universitas Udayana

Davidson, Robin. 2010. An Introduction to Coastal Process and Geomorphology. Network : Cambridge University Press

Erni Suharini dan Abraham Palangan. 2014. Geomorfologi: Gaya, Proses, dan Bentuklahan. Jogjakarta: Penerbit Ombak 
Halim. 2016. Studi Perubahan Garis Pantai Dengan Pendekatan Penginderaan Jauh Di Wilayah Pesisir Kecamatan Soropia. Jurnal. Kendari. E- ISSN 2503-0396

Hardjowigeno. 1990. IImu Tanah. Jakarta. Akademika Pressindo

http://jateng .tribunnews.com/2018/05/28/136313-hektar-wilayah-kota-pekalonganterendam-air-rob. Diakses pada 25 Maret 2019.

Kurnianto, Fahmi Arif. 2019. Keberagaman Bentuk Lahan Di Wilayah Pesisir Dan Kaitannya Dengan Karakteristik Proses Geomorfologi. Jurnal. Jember. Universitas Jember

Nazir. 2010. Analisis Determinan Pendapatan Pedagang Kaki Lima di Kabupaten Aceh Utara. Tesis. Medan. Universitas Sumatera Utara.

Ongkosongo, O.S.R. 2006. Laporan Pengamatan Pantai Jambo Timu-Lancok Kabupaten Lokseumawe, Propinsi Nanggroe Aceh Darussalam: 59 hal.

Pranoto, Sumbogo. 2010. Prediksi Perubahan Garis Pantai Menggunakan Model GENESIS. Jurnal. Teknik Keairan. Jurusan Teknik Sipil UNDIP.

Rizal. 2002. Dampak Perubahan Penggunaan Lahan Sepanjang Pantai Ujong Blang Lokseumawe Terhadap Pemunduran Garis Pantai, Jurnal EKOTON, 2(1): 2530.

Salim, Abdul Rasyid, dkk. 2011. Kajian Pemanfaatan Ruang Kawasan Pesisir Kabupaten Bone Bolango Yang Berwawasan Lingkungan (Studi Kasus Desa Botubarani Dan Desa Huangobotu), Jurnal Ilmu Lingkungan Vol.9, No. 1, April 2011

Setiyarso, Budi. 2015. Analisis Perubahan GAris PAntai dan Perubahan Penggunaan Lahan Pesisir Kabupaten Rembang tahun 2003-2014. Thesis FKIP UNS

Sugiyono. 2011. Metode Penelitian Pendidikan. Bandung : Penerbit Alfabeta

Sutanto. 1994. Penginderaan Jauh Jilid 1. Yogyakarta : Penerbit Gadjah Mada University Press

Sutanto. 2016. Penginderaan Jauh untuk Lingkungan dan Konservasi. Yogyakarta : Penerbit Ombak

Tika, Moh Pabundu. 1997. Metode Penelitian Geografi. Jakarta : PT. Gramedia Pustaka Utama

Undang-Undang Republik Indonesia No. 13 Tahun 2003 Tentang Ketenagakerjaan

Undang-Undang No. 20 Tahun 2003. Tentang Sistem Pendidikan Nasional.

Wu, X., Z. Shen, R. Liu, and X. Ding .2008. "Land Use/Cover Dynamics in Response to Changes in Env ironmental and Socio-Political Forces in the Upper Reaches of the Yangtze River, China". Sensors, 8: pp. 8104-8122.

Yunus, Hadi Sabri. 2011. Manajemen Kota Perspektif Spasial. Yogyakarta : Pustaka Pelajar

Yuwono, Nur. 1999. Teknik Pantai, Dasar-Dasar Perencanaan Pembangunan Pantai, Volume II. Laboratorium Hidraulika dan Hidrologi, PAU-IT Yogyakarta : Gadjah Mada University Press 